\title{
Effect of Geopolymer Concrete Encased I- Section and Geopolymer CFST Column Under Fire
}

\author{
Md Mustafeezul Haque, Sabih Ahmad, Abdul Hai, Md Marghoobul Haque
}

\begin{abstract}
Geopolymer concrete can resist fire quite well when compared with conventional concrete. Recent studies to observe the behaviour of geopolymer composite column under the effect of fire are very few. In this paper results in terms of stress, strain and deformation of geopolymer composite column expressed to elevated temperature are presented. It was observed that geopolymer composite column performs better at elevated temperatures than the conventional composite column. This tests are performed with four composite column with geopolymer concrete and conventional concrete which is tested at four elevated temperatures i.e., $400{ }^{\circ} \mathrm{C}, 500^{\circ} \mathrm{C}, 600^{\circ} \mathrm{C}, 700^{\circ} \mathrm{C}$ and 800 ${ }^{\circ} \mathrm{C}$ to evaluate the strength parameters. It results geopolymer concrete column can be used where fire disaster chances are high.

Keywords: ANSYS, CFST Column, Composite Column, Elevated Temperature, Finite Element Method, Geopolymer Concrete.
\end{abstract}

\section{INTRODUCTION}

CFST columns are widely used as compression member in multistorey building. The structural of CFST column are, high strength, large stiffness and high ductility as well as easy construction and omission of formwork. Accidental fire remains a high risk for building structures, which may lead to civilian casualties and high cost for repairing structural damage. In the worst scenario, uncontrolled fire can cause total damage which may lead to collapse of the structure. Although conventional concrete can resist fire to some extent however severe fire exposure results in spalling of concrete due to which concrete loses its strength. Recently, geopolymer concrete (GPC) has been developed as an environmentally friendly alternative to conventional concrete. Cement production is increasing every year with the increasing demand for construction industries. The annual increase in cement production globally is $3 \%$. Therefore, the rate of carbon dioxide release into the atmosphere during cement production is also increasingMore

Manuscript received on August 19, 2021.

Revised Manuscript received on August 23, 2021.

Manuscript published on August 30, 2021.

* Correspondence Author

Md Mustafeezul Haque*, Pursuing M.Tech, Civil Engineering, Integral University, Lucknow, India. Email: mustafeez012@gmail.com

Dr. Sabih Ahmad, Associate Professor and Former Head, Civil Engineering, Integral University, Lucknow, India.. Email: sabih@iul.ac.in

Abdul Hai, Pursuing M.Tech, Civil Engineering, Integral University, Lucknow, India.Email: abdulh8075@gmail.com

Md Marghoobul Haque, Pursuing M.Tech, Civil Engineering, NIT Jalandhar, India. Email: haquemarghoob@gmail.com

(C) The Authors. Published by Blue Eyes Intelligence Engineering and Sciences Publication (BEIESP). This is an open access article under the CC BY-NC-ND license (http://creativecommons.org/licenses/by-nc-nd/4.0/) than 100 million tons of fly ash are produced annually in India. Out of the 100 million only 20\% (20 million) is used in concrete or something else like soil stabilization. Most of the fly ash is disposed of as waste material on useful and valuable lands which can be used for other purposes. This study is based on behavior of Geopolymer concrete column. Two types of columns are considered for the study one is concrete encased I section column and another is concrete filled steel tubular column with conventional cement concrete and geopolymer concrete. The behavioral comparison between the conventional concrete composite columns and geopolymer composite concrete columns by applying axial load of $2500 \mathrm{KN}$ under the effect of temperature of $400{ }^{\circ} \mathrm{C}$, $500{ }^{\circ} \mathrm{C}, 600{ }^{\circ} \mathrm{C}, 700{ }^{\circ} \mathrm{C}, 800{ }^{\circ} \mathrm{C}$ for the parameter of deformation, Stress and Strain were studied. Recent researches are carried out to observe the behavior of composite structures are presented here.

Shaikh and Vimonsatit, 2015; Pan and Sanjavan, 2012; Vickers et al., 2016 In this study it was established that geopolymer can be used as a binder to make GPC which performs better than OPC concrete when exposed to fire. This is owing to the fact that geopolymer has a three-dimensional network structure of interconnected aluminate and silicate tetrahedra, which is very stable at elevated temperatures.

Shi et al. (2015) carried out an experimental investigation on short geopolymeric recycled concrete-filled steel columns with a square cross-section. The test results were compared with those of CFST columns made with cement-based recycled aggregate concrete. In their research, the two types of concrete developed similar compressive strengths at the time of testing. However, it was reported that the load-carrying capacities of the geopolymer CFST columns were 23 26\% higher than those of the cement based CFST columns when no recycled aggregate was added to the concrete. On the other hand, both geopolymer and cement-based CFST columns had comparable load carrying capacities when $50 \%$ or $100 \%$ natural coarse aggregate was replaced by recycled aggregate. Another research finding reported by Shi et al. (2015) is that geopolymer CFST columnshad smaller peak strains corresponding to the peak loads compared with the cement based CFST counterparts.

Espinos et al. (2015) conducted a numerical analysis to investigate the fire performance of concrete-filled double tube columns. For a typical OPC-filled double-tube column, the predicted fire resistance time is $87 \mathrm{~min}$. When GPC presents at the ring between the inner and the outer steel tubes, the predicted fire resistance time increases to $139 \mathrm{~min}$.

Published By:

Blue Eyes Intelligence Engineering and Sciences Publication

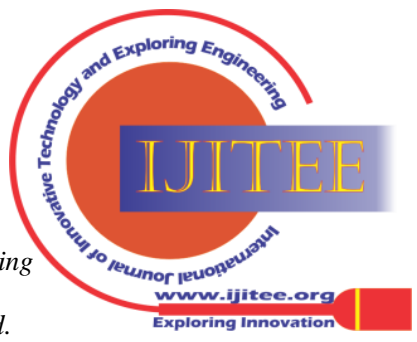


Espinos et al. (2015) attributed the increase in fire resistance to the delay in the temperature rise of the inner tube because of the outer geopolymer concrete. In their simulation, a relatively low thermal conductivity of $0.43 \mathrm{~W} / \mathrm{m} \mathrm{K}$ was adopted for GPC. In contrast, the values of thermal conductivity for OPC concrete encased in a steel tube are 2.29, 1.26, and $0.74 \mathrm{~W} / \mathrm{m} \mathrm{K}$ at 20,500 , and $1000^{\circ} \mathrm{C}$, respectively, according to a model proposed in (Tao and Ghannam, 2013). The difference in thermal conductivity between the two materials partly explains the difference in predicted fire resistance time

The above literature review indicates that no test results of composite column with geopolymer concrete have been reported. Meanwhile, no fire or post-fire tests have been carried out on geopolymer concrete encased I- section column and GCFST columns. To address the research gaps, a series of fire simulation analysis using ANSYS 17.2 by applying axial load were conducted on the above columns. Reference specimens made with conventional concrete were also analyzed to compare with the geopolymer concrete column specimens. A finite element model (FEM) developed for conventional CFST columns to compare the results with geopolymer CFST columns and another is conventional concrete encased I-section to compare with the results of Geopolymer concrete encased I-section.

Geopolymer Concrete. Joseph Davidovits in the year 1978 proposed the name Geopolymer concrete (GPC). GPC is produced by complete replacement of cement with fly ash and blast furnace slag. As a result of this geopolymer concrete reduces carbon emissions by $80 \%$. Heat is not required while making geopolymer concrete and therefore it does not produce carbon dioxide. When we compare GPC with conventional concrete, GPC is more resistant to corrosion and fire, has high compressive and tensile strengths, and it requires less time to gain its full strength (cures fully faster).

Composite Column. A concrete composite is a compression member and in present study it is classified as a) encased with concrete and b) filled with concrete. It is a member that transfers load from the beam to the foundation. Composite columns are a combination of two traditional core structures: additive steel and core cement. Composite columns are a combination of traditional structural materials, one of which is structural metal and the other is structural concrete. Because composite columns were typically developed after metal and fortified steel sections, their structure technology could have been absolutely based on either steel or steel plan strategies. However, the planning of steel column methods differed from the planning of concrete methods in some basic methods. Regardless, any of the design techniques can be used as an introduction to developing a layout technology for composite columns. Fig 1 and Fig 2 shows the typical cross-sections of composite members with wholly and partly concrete encased and concrete-filled steel members respectively.

Composite Column types. Two types of composite column are there one is concrete encased section and another is concrete filled section. A concrete-filled steel column makes use of both materials concrete as well as steel. Generally, if we consider different cross sections of steel tubular column like of square, rectangular or circular shapes. They are filled with reinforced concrete or ordinary. These types of columns are usually used in multi-storey buildings or in the structures of high-rise, and if we consider in the case of a low-rise building, these composite elements are used as a beam mostly in industrial buildings where an efficient and useful structural system is required. We also realize that thin-walled steel tube sections have a warping problem when carrying a heavy load, so their use has been limited. This problem can be solved by using concrete as a filler in these tubular sections. Due to the confining effect of the steel structure on the concrete core, the performance of these elements is improved and also the presence of the concrete core improves the resistance against torsion, thus helping the entire structural system to perform efficiently. The steel is furnished on the outer surface of the shaft, thus the behavior of the shaft changes in an effective manner when it encounters buckling and torsional forces. Concrete that is present inside as a core material have good stiffness and therefore it resists axial compression.

\section{Concrete - filled columns}

- Circular Concrete Filled Steel Tube (CCFST)

- Rectangular Concrete filled Steel Tube (RCFST)

- Square Concrete filled Steel Tube (SCFST)

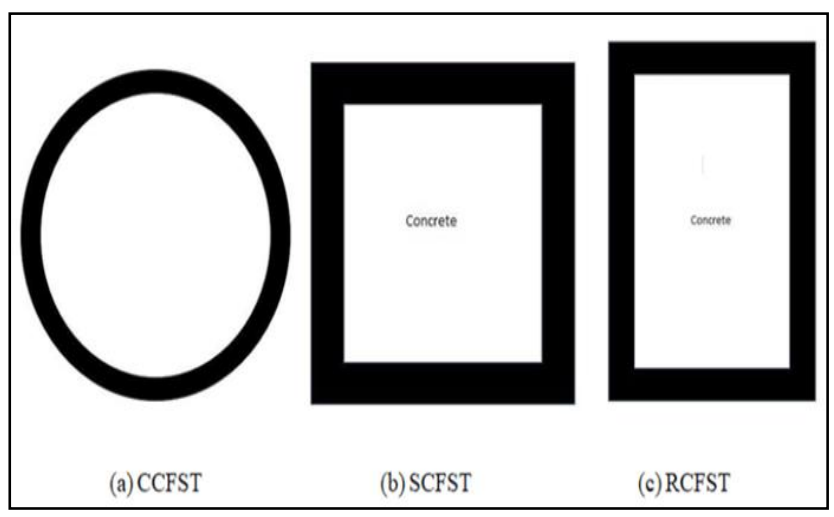

Fig. 1 Concrete filled column section

\section{Concrete encased columns}

- Totally encased Concrete Filled Section

- Partially encased Concrete Filled Section
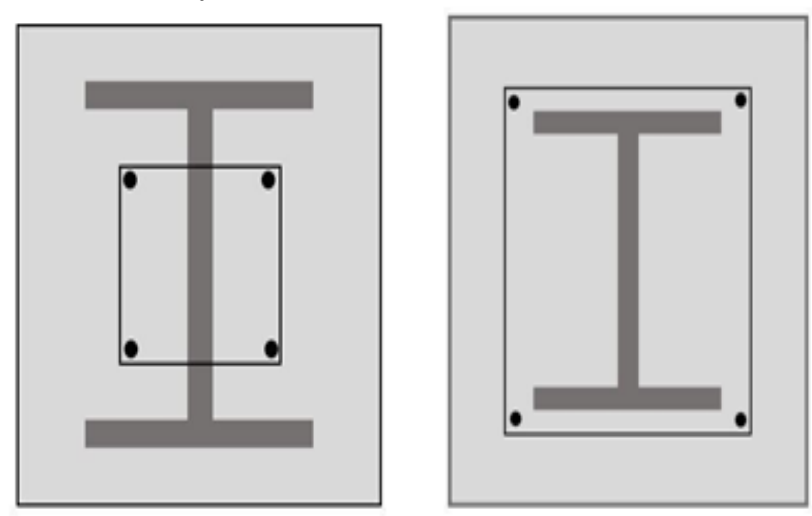

Fig. 2 Totally encased concrete filled section

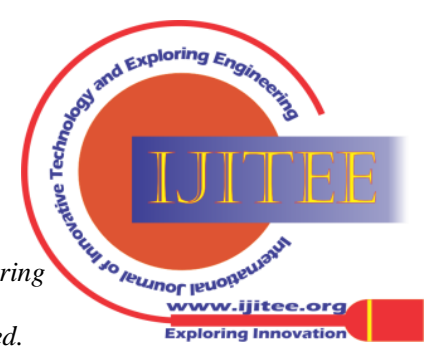



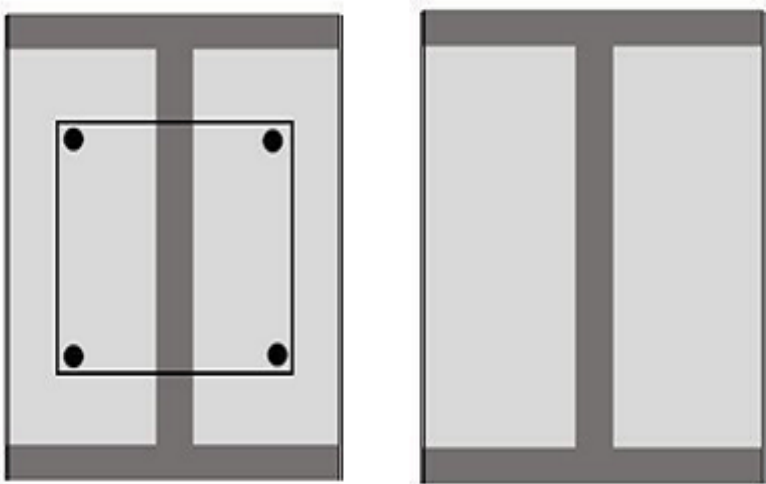

Fig. 3 Partly encased concrete filled section

In Fig. 1 cross section of column is shown where concrete is filled inside different shapes of hot steel tube.

In Fig. 2 cross section of column is shown where structural steel is embedded in concrete in two ways i.e., wholly encased or with partly encased.

\section{Objectives}

1. Comparative study of fire behaviour of two different type of columns

- Conventional concrete filled steel tubular column (CCFST) with geopolymer concrete filled steel tubular column (GCFST)

- Conventional concrete encased I - section with geopolymer concrete encased I - section.

2. To compare the parameters like deformation, stress, strain of a conventional composite column and geopolymer composite column using ANSYS

\section{ANALYTICAL DETAILS}

\section{A. Properties of Material Used}

Two types of concrete are used, Geopolymer concrete and conventional concrete. These properties are entered in ANSYS for simulation

Table 1 Material Properties

\begin{tabular}{|c|c|c|}
\hline S.no & Material & Mechanical properties \\
\hline \multirow{4}{*}{01} & \multirow{4}{*}{ Concrete } & Density $=2400 \mathrm{~kg} / \mathrm{m}^{3}$ \\
\hline & & $\begin{array}{c}\text { Compressive Strength } \\
=30 \mathrm{Mpa}\end{array}$ \\
\hline & & $\begin{array}{l}\text { Yong's Modulus } \\
=30000 \mathrm{Mpa}\end{array}$ \\
\hline & & Poisson's ratio $=0.20$ \\
\hline \multirow{3}{*}{02} & \multirow{3}{*}{$\begin{array}{c}\text { Geopolymer } \\
\text { Concrete }\end{array}$} & Density $=2371.7 \mathrm{~kg} / \mathrm{m}^{3}$ \\
\hline & & $\begin{array}{l}\text { Young's modulus } \\
=32800 \mathrm{Mpa}\end{array}$ \\
\hline & & Poisson's ratio $=0.18$ \\
\hline
\end{tabular}

\section{B. Details of Models}

Four columns of dimensions given in Table-2 and Table-3 is modelled for analysis. In these columns mild steel and I section were used. The loading on all the columns is kept the same. The columns are modelled and analyzed using ANSYS 15. Table 4 shows the load and temperature consideration for analysis.

Table 2 Details of CFST column

\begin{tabular}{|c|c|c|}
\hline S. No & Description & Specification \\
\hline 1 & Steel type & Mild Steel \\
\hline 2 & $\begin{array}{c}\text { Diameter of } \\
\text { steel tube }\end{array}$ & $600 \mathrm{~mm}$ \\
\hline 3 & $\begin{array}{c}\text { Thickness of } \\
\text { steel tube }\end{array}$ & $14 \mathrm{~mm}$ \\
\hline 4 & $\begin{array}{c}\text { Height of } \\
\text { Column }\end{array}$ & $3200 \mathrm{~mm}$ \\
\hline 5 & $\begin{array}{c}\text { Grade of } \\
\text { Concrete }\end{array}$ & M30 \\
\hline
\end{tabular}

Table 3 Details of concrete encased column

\begin{tabular}{|c|c|c|}
\hline S. No & Description & Specification \\
\hline 1 & $\begin{array}{c}\text { Steel section } \\
\text { used }\end{array}$ & ISMB 600 \\
\hline 2 & $\begin{array}{c}\text { Column } \\
\text { dimension }\end{array}$ & $300 \mathrm{~mm} \times 650 \mathrm{~mm}$ \\
\hline 3 & Cover & $35 \mathrm{~mm}$ \\
\hline 4 & $\begin{array}{c}\text { Height of } \\
\text { Column }\end{array}$ & $3200 \mathrm{~mm}$ \\
\hline 5 & $\begin{array}{c}\text { Grade of } \\
\text { Concrete }\end{array}$ \\
\hline
\end{tabular}

Table 4 Loading Details

\begin{tabular}{|c|c|c|}
\hline S. No & Description & Specification \\
\hline 1 & $\begin{array}{c}\text { Axial Load } \\
\text { Applied }\end{array}$ & $2500 \mathrm{KN}$ \\
\hline 2 & $\begin{array}{c}\text { Temperature } \\
\text { considered }\end{array}$ & $\begin{array}{c}400^{\circ} \mathrm{C}, 500^{\circ} \mathrm{C}, 600^{\circ} \mathrm{C}, 700^{\circ} \mathrm{C} \\
\text { and } \\
800^{\circ} \mathrm{C}\end{array}$ \\
\hline
\end{tabular}

Published By:

Blue Eyes Intelligence Engineering and Sciences Publication 


\section{Model Names}

Model name is assigned for comparing different models with others, plotting graphs and for further analysis.

Table 5 Model Names

\begin{tabular}{|c|c|c|}
\hline S. No & Model Name & Model Detail \\
\hline 1 & Model 1 & $\begin{array}{c}\text { convention } \\
\text { concrete encased } \\
\text { I-section }\end{array}$ \\
\hline 2 & Model 2 & $\begin{array}{c}\text { geopolymer } \\
\text { concrete encased } \\
\text { I-section }\end{array}$ \\
\hline 3 & Model 3 & $\begin{array}{c}\text { conventional } \\
\text { concrete filled } \\
\text { steel tubular } \\
\text { column }\end{array}$ \\
\hline 4 & Model 4 & $\begin{array}{c}\text { geopolymer } \\
\text { steel tubular } \\
\text { column }\end{array}$ \\
\hline
\end{tabular}

\section{MODELLING AND ANALYSIS}

The analysis of the models will be done on ANSYS Workbench ver. 17.2 [9] by using this software there is an inbuilt material data library by which we change its mechanical properties. Concrete, steel is taken by ANSYS library and properties of geopolymer concrete are inserted then modified it as per the requirement and create geometry of the required model as shown in Fig 4 to analyze and apply dense tetra meshing for finite element analysis (FEA) of models. After this apply loads and supports boundary condition then add parameters (Total Deflection, Stress, Strain) to check the results of each model.
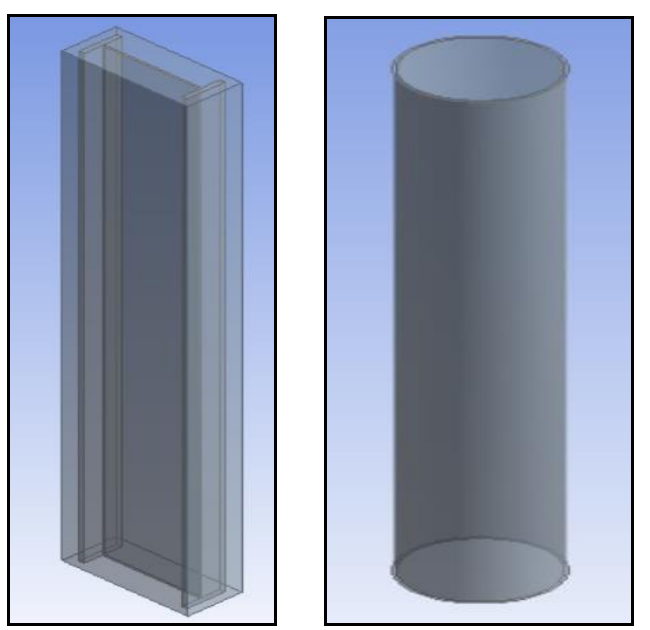

Fig. 4 Models of Concrete encased I-section and CFST column

In the Fig. 5 MODEL is solved by ANSYS solver for further analysis. It's shown on both figures Concrete, I-section \& mild steel is tetra meshed. MODEL is ready for analysis \& it is solved by the method of finite element analysis (FEA).

\section{RESULTS AND DISCUSSION}

The extensive numerical simulation was performed on concrete filled steel tube columns against axial loading with elevated temperature of $400^{\circ} \mathrm{C}, 500^{\circ} \mathrm{C}, 600^{\circ} \mathrm{C}, 700^{\circ} \mathrm{C}$ and
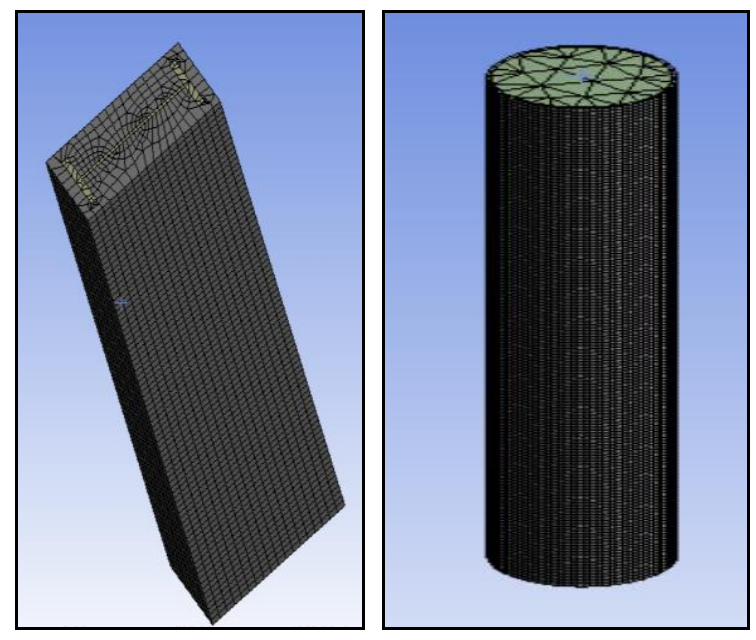

Fig. 5 Meshing of concrete encased I-section and CFST column

$800^{\circ} \mathrm{C}$ for all specimens such as Model 1, Model 2, Model 3, and Model 4. The parameters such as deflection, stress and strain in concrete filled steel tubular columns and concrete encased I-section column were studied for all columns against axial thermal loading. The results obtained in terms of deflection, stress and strain on the geopolymer concrete core were compared with conventional concrete core and presented in detail

\section{Published By:}

Blue Eyes Intelligence Engineering and Sciences Publication

(C) Copyright: All rights reserved.

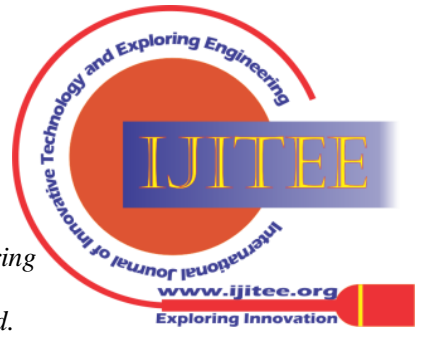




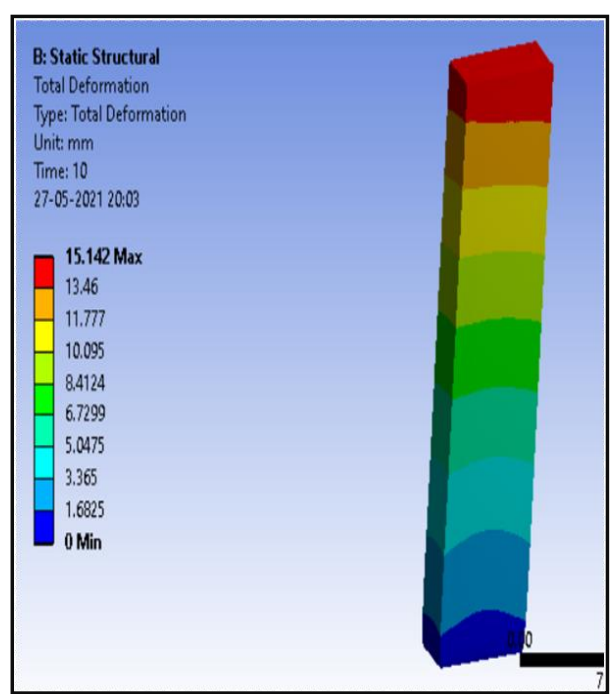

Fig. 6 Deformation result of Model 1

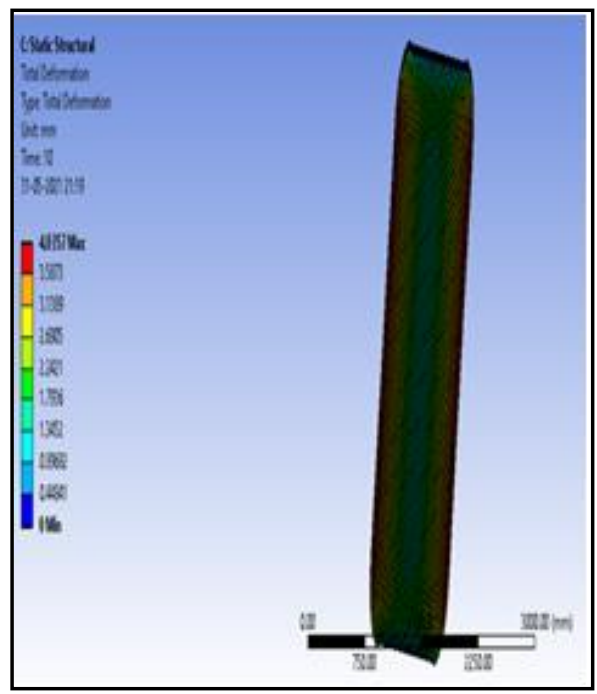

Fig. 7 Deformation result of Model 2

In the Fig. 6 Model 1 showing the contour diagram after analysis \& generate maximum 15.142mm deflection. In the Fig. 7 Model 2 showing the contour diagram after analysis \& generate maximum 6.142mm deflection.

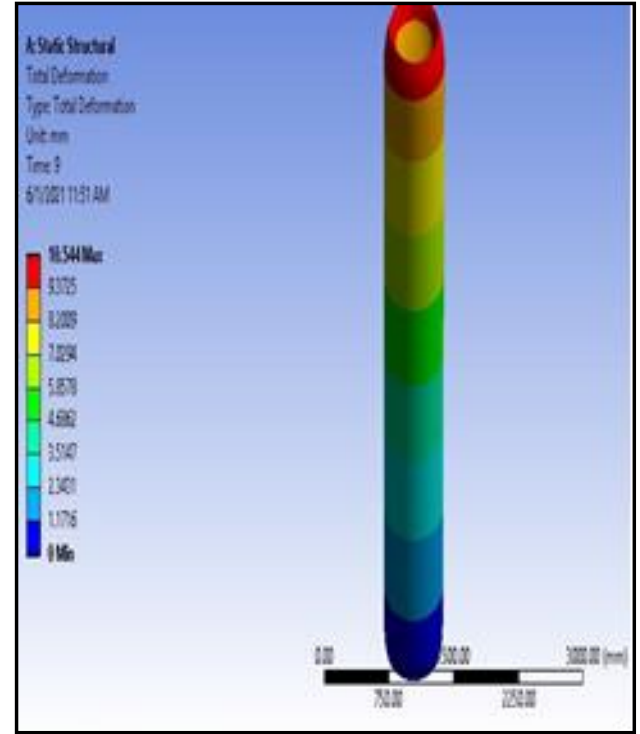

Fig. 8 Deformation result of Model 3

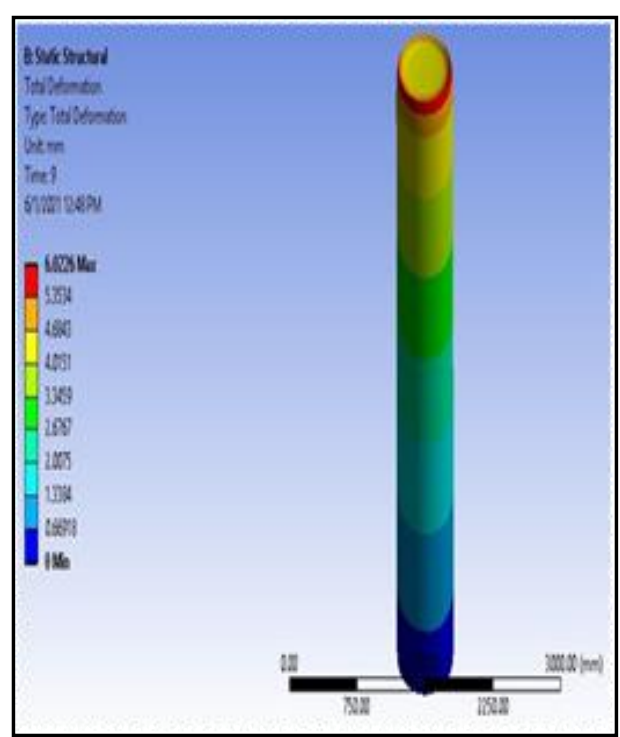

Fig 9 Deformation Result of Model 4

In the Fig. 8 Model 3 showing the contour diagram after analysis \& generate maximum 10.544mm deflection. In the Fig. 9 Model 4 showing the contour diagram after analysis \& generate maximum 6.026mm deflection.

Table-6 Data for Deformation, Stress and Strain

\begin{tabular}{|c|c|c|c|c|}
\hline S. No & Model & $\begin{array}{c}\text { Deformation } \\
\mathbf{( m m )}\end{array}$ & Equivalent Stress (MPa) & $\begin{array}{c}\text { Strain } \\
(\mathbf{m m})\end{array}$ \\
\hline 1 & Model 1 & 15.142 & 5848.5 & 0.0624 \\
\hline 2 & Model 2 & 6.142 & 11575 & 0.0809 \\
\hline 3 & Model 3 & 10.544 & 2663 & 0.0146 \\
\hline 4 & Model 4 & 6.026 & 5028 & 0.0251 \\
\hline
\end{tabular}

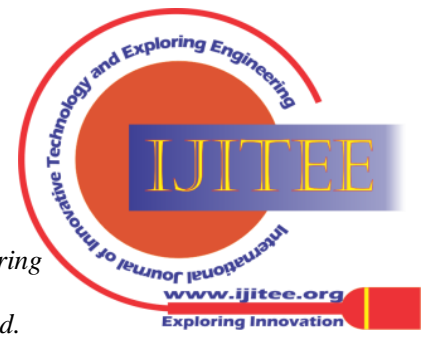


Effect of Geopolymer Concrete Encased I- Section and Geopolymer CFST Column Under Fire
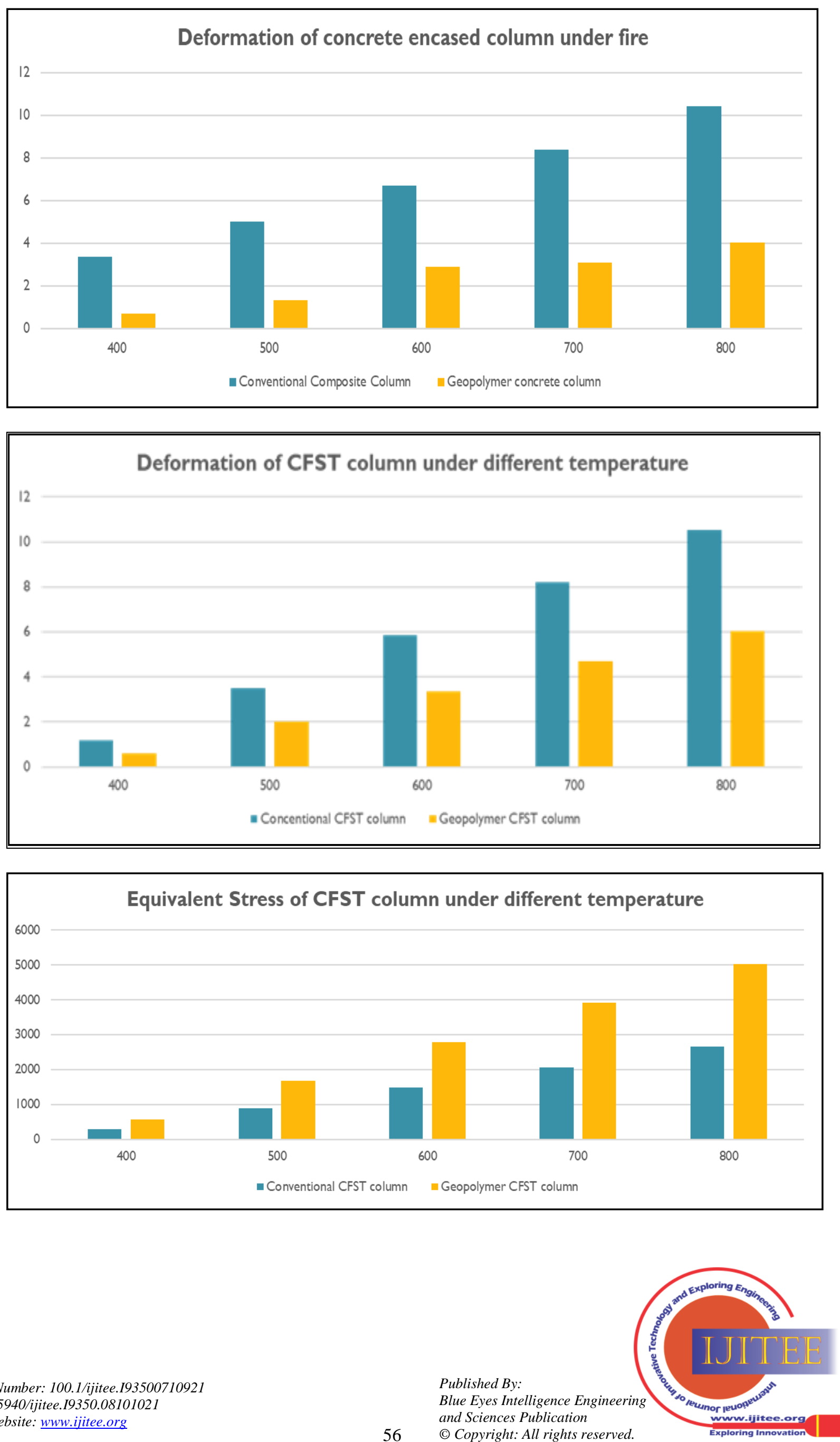


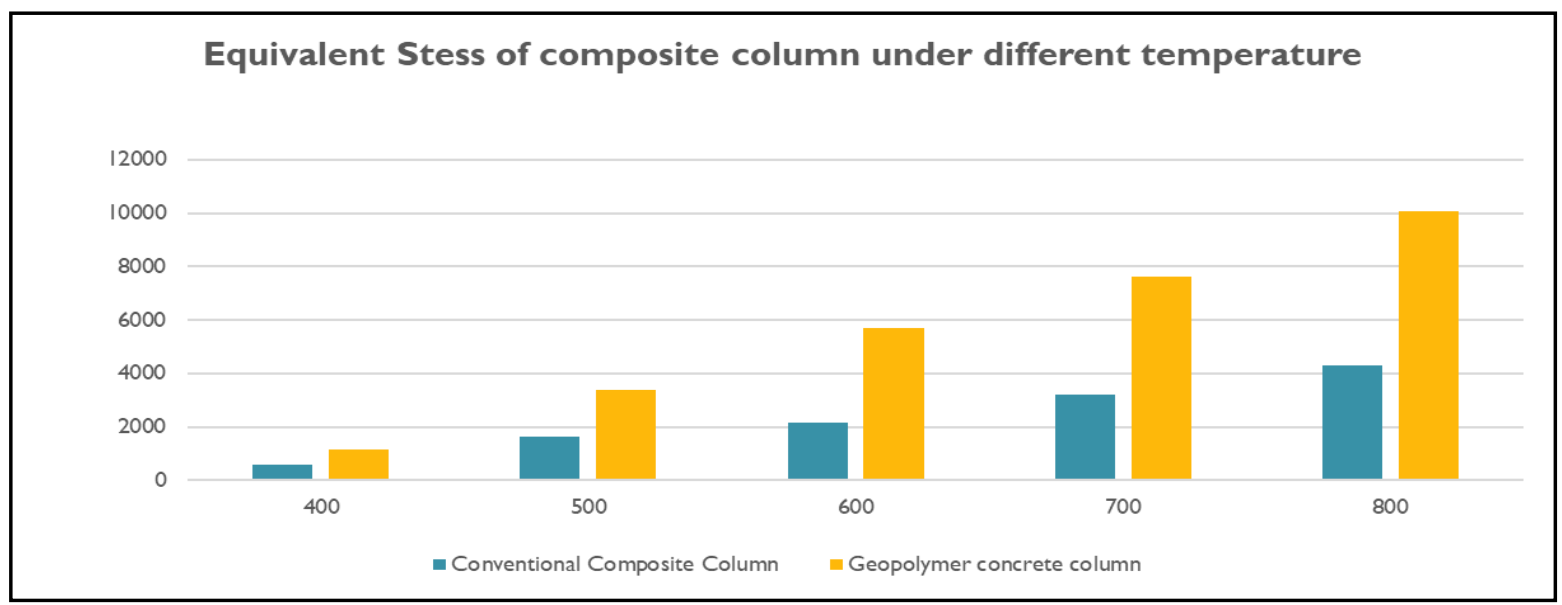

Graph-1 Results obtained for difference response parameter under different temperature

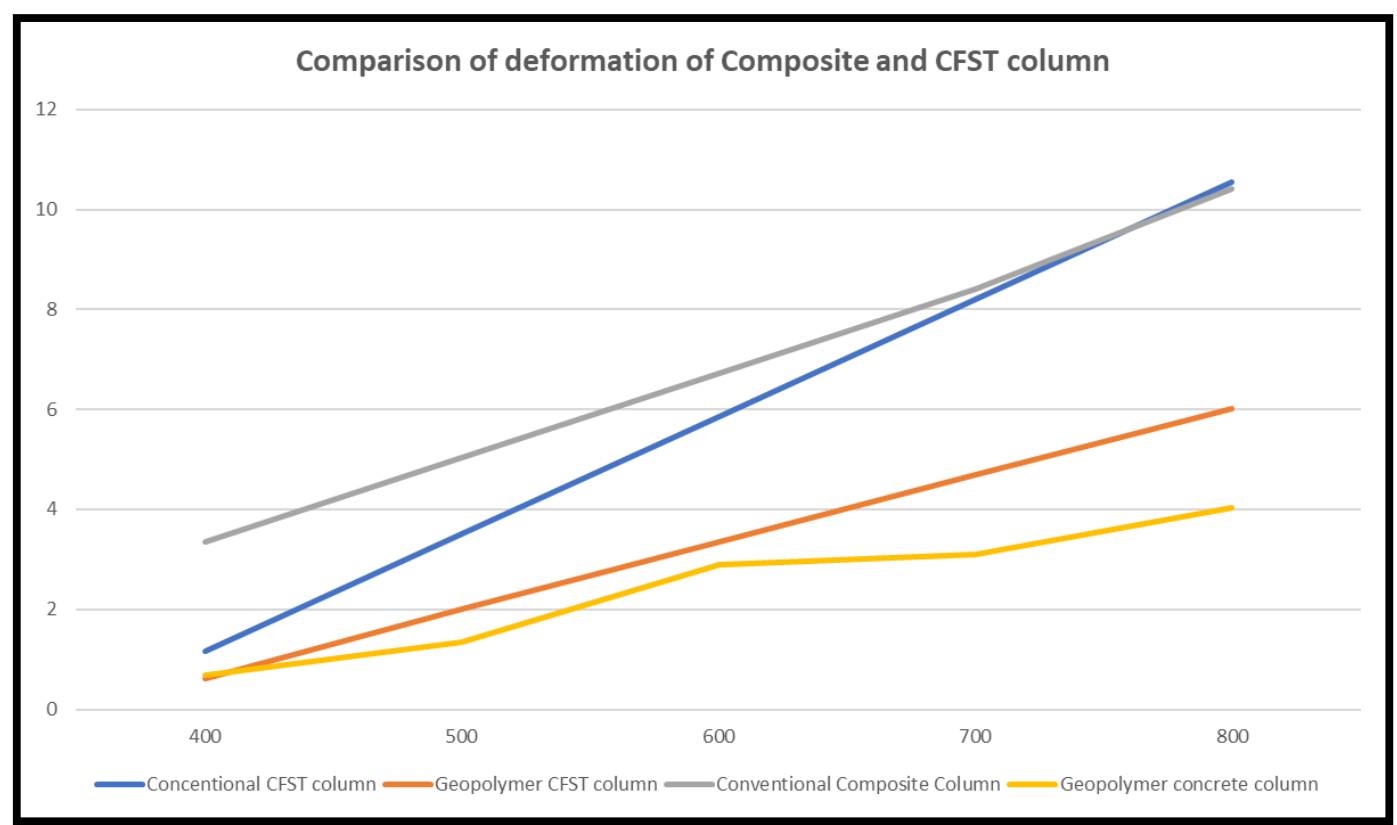

Graph-2 Comparison of concrete encased column with concrete filled column in terms of deformation

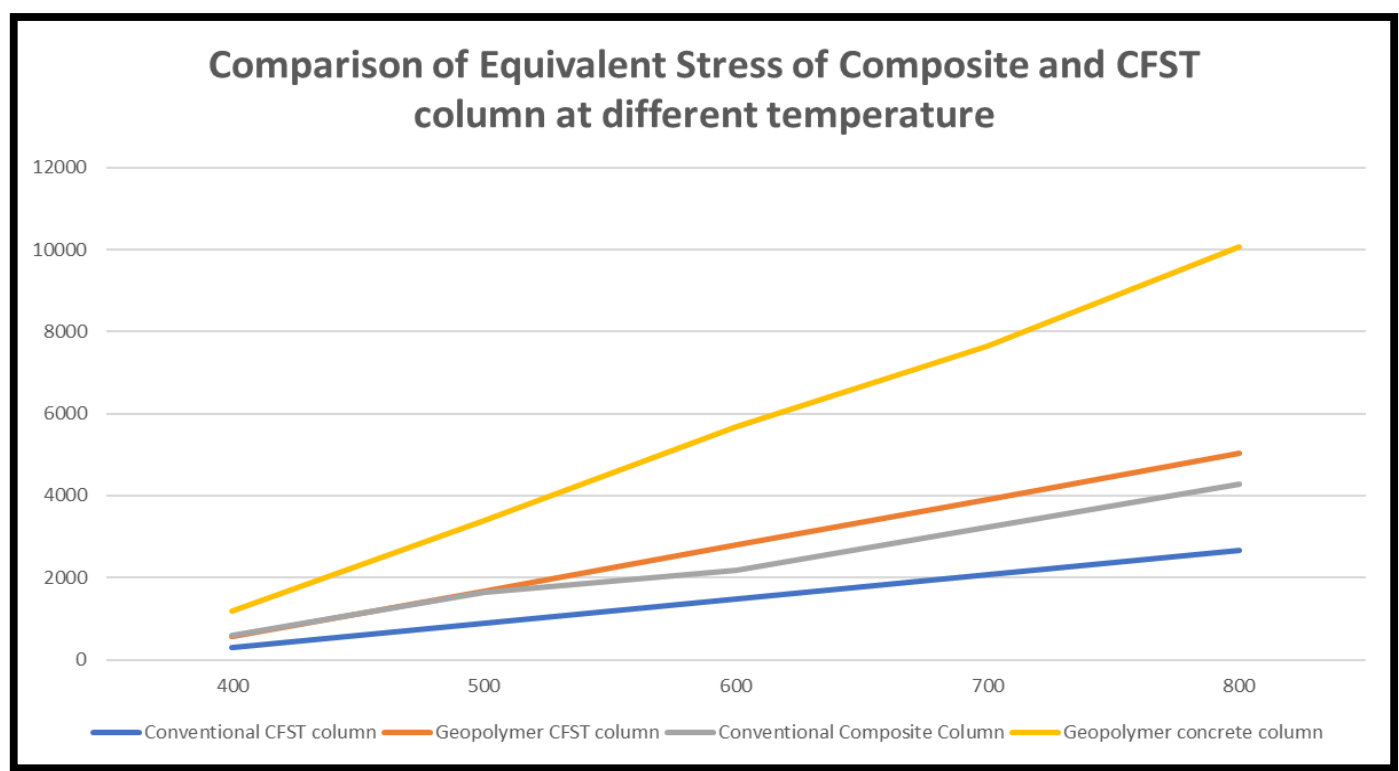

Graph-3 Comparison of concrete encased column with concrete filled column in terms of equivalent stress

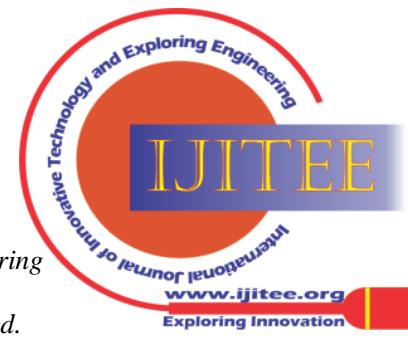




\section{CONCLUSION}

From the above results, it is concluded that there is a benefit of Geopolymer concrete column rather than conventional concrete column for elevated temperature. It's seems in analysis of CFST column, conventional concrete column generate greater deflection on the other hand geopolymer concrete column is around $41.04 \%$ more save in deflection. As per analysis results geopolymer encased I section have $50.52 \%$ large effective stress as compare with conventinal concrete encased I-section. It can be said that GCFST column have good fire resistant properties as compare to conventional concrete. The fire endurance of CFST columns under combined loading and elevated temperatur can be extensively improved by using GPC (especially heat cured GPC) as core concrete.

The concept of the geopolymer used in CFST columns is to make column more resistant to fire and also it is lighter than that of RCC columns. As a result, damage is less and the foundation cost is reduced and the resulting earthquake force is also reduced. CFST columns are safer and more dependable in the seismic regions as generally the high-strength concrete is used and the brittle failure can also be prevented

\section{REFERENCES}

1. João Paulo C. Rodrigues 2018; Comparing fire behaviour of restrained hollow stainless steel with carbon steel columns, Journal of Constructional Steel Research (JCSR)

2. Sherif A. Elsawaf and Maha M. Hassan 2018; Behaviour of structural steel beams with openings in fire conditions, Journal of Constructional Steel Research (JCSR)

3. D. Winful K.A. Cashell, 2018;Behaviour of high strength steel columns under fire conditions, Journal of Constructional Steel Research (JCSR).

4. Hussam Mahmoud,2019; Collapse performance of composite steel frames under fire, Engineering Structures.

5. Guo-Qiang Li, Xin-Xin Wang, 2020; Creep behavior and model of high-strength steels over $500 \mathrm{MPa}$ at elevated temperatures, Journal of Constructional Steel Research (JCSR).

6. An He, Hai-Ting Li, 2020 ;Flexural buckling behaviour and residual strengths of stainless steel CHS columns after exposure to fire, Thin-Walled Structures.

7. L. Twilt, R. Hass, W. Klingsch, M. Edwards, and D. Dutta. 1994. Design Guide for Structural Hollow Section Columns Exposed to Fire. Verlag TUV Rheinland GmbH, CIDECT, Koln Germany. 16-18.

8. Hung, W. Y. and Chow, W. K. 2002. Review on the Requirements on Fire Resisting Construction. International Journal of Engineering Performance-based Fire Codes. 4(3): 68-83.

9. Petterson. O., Magnusson. S. and Thor. J. 1976. Fire Engineering of Steel Structures. Publication 50, Swedish Institute of Steel Construction, Stockholm.

10. H. Yang, F. Q. Liu, S. M. Zhang, and X. T. Lv: Engineering Structures, Vol. 48 (2013), p. 292

11. H. Yang, F. Q. Liu, and L. Gardner: Engineering Structures, Vol. 56 (2013), p. 1986

12. Kotha Yasaswini, A. Venkateshwara Rao. Behaviour of geopolymer concrete at elevated temperature. Materials Today: Proceedings

13. ISO 834

14. IS 456- 2000

15. Lin-Hai Han, Wei-Hua Wang, Hong-Xia Yu. Analytical behaviour of RC beam to CFST column frames subjected to fire. Engineering Structures 36 (2012) 394-410.

16. Qian-Yi Song a,b, Lin-Hai Han a,*, Kan Zhou a, Yuan Fengb, Fire resistance of circular concrete-filled steel tubular (CFST) column protected by intumescent coating. Journal of Constructional Steel Research 147 (2018) 154-170

17. Kan Zhou, Lin-Hai Han, Modelling the behaviour of concrete-encased concrete-filled steel tube (CFST) columns subjected to full-range fire. Engineering Structures 183 (2019) 265-280.

18. Ying Guo1 and Yufen Zhang, Comparative Study of CFRP-Confined CFST Stub Columns under Axial Compression. Hindawi, Advances in
Civil Engineering Volume 2018, Article ID 7109061. https://doi.org/10.1155/2018/7109061

19. Sangdo Hong, Amit H. Varma, 2009; Analytical modeling of the standard fire behavior of loaded CFT columns, Journal of Constructional Steel Research 65 (2009) 54-69.

20. Thomas, R.J., Peethamparan, 2015; Alkali-activated concrete: Engineering properties and stress-strain behavior. Constr. Build. Mat., 93, 49-56

21. Husain, M., Hassan, H., \& Salama, E. (2016). Analysis of concrete columns Reinforced by Fiber Reinforced Polymers Bars, 6(5), 1-8.

\section{AUTHORS PROFILE}

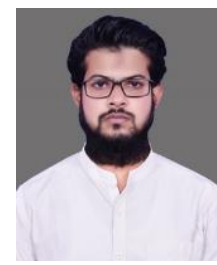

Md Mustafeezul Haque, was born in 1996 in Patna, Bihar. $\mathrm{He}$ is pursuing M.Tech in Structural Engineering from Integral University Lucknow, India. He completed his B.Tech in Civil Engineering from Jawaharlal Nehru Technological University, Hyderabad, India.

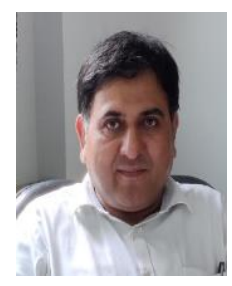

Dr. Sabih Ahmad, was born in 1971 in Aligarh city, Uttar Pradesh. He received his B.Sc Engineering (Civil) from A.M.U, in 1994. In 2002 he received his Master's Degree in Structural Engineering from A.M.U, Aligarh, and Ph.D. in Civil Engineering in 2018 from Integral University, Lucknow. He has a vide experience in teaching, research at UG and PG levels. Presently he is Associate Professor and Former Head of the Department of Civil Engineering at Integral University, Lucknow. Additionally, he was awarded the Research Excellence Award (2017) for his research work in the field of Soil Engineering. He has authored numerous research papers in National and International Journals/Conferences. He is also a Member of Institution of Engineers as well as Geotechnical Society (Delhi Chapter). Also four research scholars are pursuing $\mathrm{Ph}$. D under his guidance.

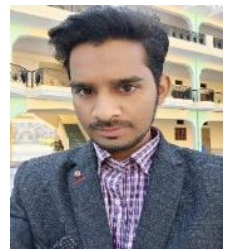

Abdul Hai, was born in 1996 in Patna, Bihar. He is pursuing M.Tech in Structural Engineering from Integral University Lucknow, India. He completed his B.Tech in Civil Engineering from Swami Vivekanand Subharti University, Meerut, India

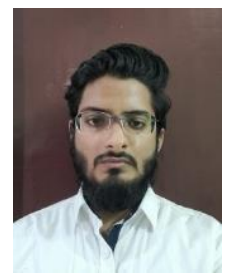

Md Marghoobul Haque, was born in 1997 in Patna, Bihar. He is pursuing M.Tech in Structural and construction Engineering from National Institute of Technology, Jalandhar. He completed his B.Tech in Civil Engineering from Aliah University, Kolkata, India
Published By:

Blue Eyes Intelligence Engineering and Sciences Publication 